\title{
CAPACITAÇÃO EM PROCESSOS DE AVALIAÇÃO MULTIDIMENSIONAL DE IMPACTOS DO CRÉDITO PRODUTIVO NA SUSTENTABILIDADE DOS ASSENTADOS RURAIS NO TERRITÓRIO SUDESTE DO PARÁ
}

\author{
Ana Caroline Neris Nogueira'; Luis Mauro Santos Silva ${ }^{2}$ \\ ${ }^{1}$ Discente do curso de Agronomia, Faculdade de Ciências Agrárias de Marabá (FCAM), Universidade Federal do Pará \\ (UFPA), Marabá, Pará. Bolsista PARD. E-mail: anacarolineris@ hotmail.com. \\ ${ }^{2}$ Docente-pesquisador da UFPA/NEAF/LASAT. E-mail: lmsilva@ufpa.br.
}

RESUMO: Historicamente, a ampliação das paisagens agrícolas tem projetado diferentes cenários para o futuro da maior floresta tropical do mundo, como por exemplo: a) investir em tecnologias de intensificação produtiva nas regiões mais aptas para a agricultura, preservando e valorizando economicamente as zonas menos impactadas pelo processo produtivo capitalista; b) assumir uma postura de planejamento preservacionista nas regiões pouco alteradas e reconstituir áreas já desmatadas; c) valorizar as relações tradicionais e a sociodiversidade ainda presente na região como formas de produção preferíveis ao futuro da região. Contudo, pensar no futuro desta região é interferir em um ambiente de riqueza social ainda pouco evidenciada. Mesmo assim, o processo de "modernização" vem se dando de forma quase inexorável, ampliando as dúvidas em relação à essência dos futuros sistemas produtivos a serem consolidados neste novo milênio. Dentro deste contexto, a região sudeste do Pará se mantém bastante emblemática e adequada para estudos mais aprofundados sobre a evolução da agricultura. Até a década de 1980, as agriculturas familiares desta região sobreviveram à revelia das políticas públicas oficiais, consolidando um protagonismo político, social e econômico diante de problemas ambientais (desmatamento) e sociais (conflitos fundiários) ocasionados pelas intervenções oficiais. Apenas na década de 1990 se inclui a agricultura familiar como foco para investimentos produtivos, garantindo crédito e assistência técnica. Contudo, a ausência de estudos sobre o impacto destas políticas agrícolas e sobre a sustentabilidade dos agroecossistemas vem inibindo uma avaliação mais precisa dos pontos positivos e negativos de tais mudanças no cenário produtivo da região. Pouco se tem avançado em reflexões sobre as possibilidades de consolidação de agroecossistemas com bases de sustentabilidade (ambiental, social e econômica, por exemplo), seja através de intervenção via assessoria técnica ou por iniciativas próprias das famílias locais. Nos mais diversos estudos de avaliações sobre os impactos da atual política agrária nacional quase inexistem leituras mais contextualizadas sobre os limites e potencialidades engendradas nos diversos contextos da agricultura familiar, em especial no espaço amazônico. Este trabalho pretende avaliar e compreender os impactos do crédito produtivo em agroecossistemas familiares, considerando seu caráter multidimensional e os atores sociais envolvidos no contexto local. Os principais passos metodológicos serão: a) construção participativa do conceito local de sustentabilidade; b) seleção de agroecossistemas familiares tidos como prioridades locais para realização da avaliação da sustentabilidade; c) definição de indicadores multidimensionais (ambiental, social e técnico-econômica), junto aos assentados; d) aplicação de entrevistas semi-estruturadas, questionário, diário de campo e observações diretas junto às famílias assentadas a serem amostradas; e) sistematização e avaliação da sustentabilidade dos agroecossistemas familiares. Será aplicada a ferramenta MESMIS adaptada para o contexto territorial. A unidade básica de análise será o agroecossistema familiar. Espera-se compreender até que ponto e de que forma o acesso ao crédito produtivo influencia as atividades desenvolvidas nos agroecossistemas familiares. Procura-se paralelamente obter um conceito local de sustentabilidade por parte dos técnicos envolvidos na prestação de serviços aos assentados da região, de forma a contrapor com a realidade das famílias assentadas e propondo indicadores que auxiliem na avaliação da sustentabilidade desses agroecossistemas.

PALAVRAS - CHAVE: Agroecossistemas familiares, indicadores.

Agroecossistemas, v. 1, n. 1, p. 11-11, 2009 